\title{
Nitric Oxide Synthase inhibition counteracts the stress-induced DNA methyltransferase 3b expression in the hippocampus of rats
}

Izaque de Sousa Maciel ${ }^{1}$, Amanda Juliana Sales ${ }^{1}$; Plinio C Casarotto ${ }^{3}$; Eero Castrén ${ }^{3}$, Caroline Biojone ${ }^{3 *}$,

\author{
Sâmia R. L. Joca ${ }^{3 *}$
}

1: School of Medicine of Ribeirão Preto, University of São Paulo, Ribeirão Preto - SP, Brazil;

2: Department of Biomolecular Sciences, School of Pharmaceutical Sciences of Ribeirão Preto, University of São Paulo, Ribeirão Preto -SP, Brazil;

3: Neuroscience Center, HiLIFE, University of Helsinki, Finland

*Correspondence to:

Dr. Sâmia R. L. Joca. School of Pharmaceutical Sciences of Ribeirão Preto (FCFRP), University of São Paulo, Avenida do café s/n, 14040-903, Ribeirão Preto, SP, Brazil, Fax: +55-16-33154880, Phone: +55-16-33154705, Email: samia@usp.br

Dr. Caroline Biojone. Neuroscience Center, HiLIFE, University of Helsinki, Haartmaninkatu 8, Helsinki, Finland. Email: caroline.biojone@helsinki.fi

\begin{abstract}
It has been postulated that activation of NMDA receptors (NMDAr) and nitric oxide (NO) production in the hippocampus is involved in the behavioral consequences of stress. Stress triggers NMDAr-induced calcium influx in limbic areas, such as the hippocampus, which in turn activates neuronal NO synthase (nNOS). Inhibition of nNOS or NMDAr activity can prevent stress-induced effects in animal models, but the molecular mechanisms behind this effect are still unclear. In this study, cultured hippocampal neurons treated with NMDA or dexamethasone showed increased of DNA methyltransferase 3b (DNMT3b) mRNA expression, which was blocked by pre-treatment with nNOS inhibitor $\mathrm{n}^{\omega}$-propyl-L-arginine (NPA). In rats submitted to the Learned Helplessness paradigm ( $\mathrm{LH})$, we observed that inescapable stress increased of DNMT3b mRNA expression at $1 \mathrm{~h}$ and $24 \mathrm{~h}$ in the hippocampus. The NOS inhibitors 7-NI and aminoguanidine (AMG) decreased the number of escape failures in LH, and counteracted the changes in hippocampal DNMT3b mRNA induced in this behavioral paradigm. Altogether, our data suggest that NO produced in response to NMDAr activation following stress upregulates DNMT3b in the hippocampus.
\end{abstract}

Keywords: nitric oxide, epigenetics, DNA methylation, DNMT3b, learned helplessness

\begin{abstract}
Abbreviations: NMDA receptor (NMDAr), nitric oxide (NO), neuronal NO synthase (nNOS), DNA methyltransferases (DNMTs), DNA methyltransferase isoform 3b (DNMT3b), n- $\omega$-propyl-L-arginine (NPA), Learned Helplessness paradigm (LH), 7-Nitroindazole (7NI), aminoguanidine (AMG), major depressive disorder (MDD), cytosine-phosphate-guanine (CpG), brain-derived neurotrophic factor (BDNF), Hypothalamic-Pituitary-Adrenal axis (HPA axis), Central nervous System (CNS), Tropomyosin receptor kinase B (TrkB), L-Arginine (L-arg), Inescapable Shocks (IS), habituated group (hab), pretest (PT), test (T), dorsal hippocampus (dHPC), ventral hippocampus (vHPC), reactive oxygen species (ROS), specificity protein (Sp), cyclic guanosine monophosphate (cGMP), protein kinase $\mathrm{G}(\mathrm{PKG})$, extracellular signal-regulated kinase (ERK), cAMP responsive-element binding protein (CREB), Sodium Nitroprusside (SNP), fragile X retardation 1 (FMR1), glucocorticoid receptor (GR).
\end{abstract}

\section{Introduction}

Exposure to unpredictable and uncontrollable stress triggers maladaptive emotional and behavioral responses associated with the development of neuropsychiatric disorders, such as post-traumatic stress disorder, anxiety and major depressive disorder (MDD) (Ulrich-Lai \& Herman, 2009; Musazzi et al., 2013; Sousa, 2016; Nava et al., 2017). Dynamic regulation of gene expression is a critical component of adaptation to stress and engages epigenetic mechanisms, a process to alter gene expression without changing the sequence of DNA nucleotides (Mahgoub \& Monteggia, 2013; Herre \& Korb, 2019). DNA methylation is one of the main epigenetic mechanisms which is central to the neurobiology of MDD (Mahgoub \& Monteggia, 2013; 
Matrisciano et al., 2016). The process involves the enzymatic addition of a methyl radical to cytosine-phosphateguanine $(\mathrm{CpG})$ group through DNA methyltransferases (DNMTs: 1, 2, 3a, 3b and L), favoring chromatin condensation and gene repression (Okano et al., 1999; Weber \& Schübeler, 2007; Elliott et al., 2010; Feng et al., 2010; Mahgoub \& Monteggia, 2013). The DNMT1 maintains DNA methylation during replication and the isoforms DNMT3a or DNMT3b are associated with de novo DNA methylation, inducing new patterns of methylation on CpG sequence (Bird, 1986; Okano et al., 1999; Elliott et al., 2010; Feng et al., 2010; Mahgoub \& Monteggia, 2013).

Exposure to stress is associated with changes in DNMTs expression and DNA methylation in the promoter region of many genes relevant to neuronal function and neuroplasticity in cortical and limbic brain regions (Vialou et al., 2013; Nagy et al., 2017). Changes in DNA methylation and DNMT levels have also been described in blood cells of depressed patients, which are sensitive to chronic antidepressant treatment (Higuchi et al., 2011; Gassen et al., 2015). Similarly, chronic antidepressant treatment attenuates DNA methylation and DNMTs levels both in vivo and in vitro (Zimmermann et al., 2012; Vialou et al., 2013; Sales \& Joca, 2018).

Direct inhibition of DNA methylation promotes antidepressant-like effects associated with increased levels of brain-derived neurotrophic factor (BDNF) in the hippocampus (Sales et al., 2011; Sales \& Joca, 2016). A growing body of evidence reports increased DNA methylation of the $B d n f$ gene promoter region in the cortex and hippocampus of rodents submitted to stress, resulting in decreased expression (Schmidt \& Duman, 2007; Adachi et al., 2008; Roth \& Sweatt, 2011; Roth et al., 2011). BDNF plays a key role in several physiological processes in the developing and mature brain, such as neurogenesis, neuroprotection and regeneration, as well as reinforcing short- and long-lasting synaptic interactions (Kowiański et al., 2018). Decreased levels of BDNF is associated with impaired synaptic transmission often described in stressed animals and MDD patients (Duman \& Duman, 2015; Castrén \& Antila, 2017; Kowiański et al., 2018).

Stress exposure leads to HPA axis activation and release of glucocorticoids, which facilitates glutamate release in limbic brain regions, a mechanism that is often associated with functional and morphological impairments induced by exposure to uncontrollable stress (Sousa \& Almeida, 2012; Duman \& Duman, 2015; Belleau et al., 2019). Activation of both glucocorticoid and NMDA receptors can regulate the activity of the enzymes involved in epigenetic mechanisms, thus regulating gene expression in response to stress (Chandramohan et al., 2008). Activation of NMDAr triggers the synthesis of nitric oxide (NO) in the brain, which can rapidly diffuse across membranes and modulate several inter- and intracellular processes (Prast \& Philippu, 2001; Guix et al., 2005). There are three major NO synthases isoforms: nNOS (neuronal; NOS1) and eNOS (endothelial; NOS3), which are constitutively expressed and Ca2+-calmodulin-dependent; and iNOS (inducible; NOS2), which is mostly expressed under inflammatory or immunological stimuli (Guix et al., 2005; Amitai, 2010). Excessive NO production induced by stress is neurotoxic and predisposes to behavioral changes and MDD (Bishop \& Anderson, 2005; Calabrese et al., 2007). Accordingly, administration of nNOS or iNOS inhibitors attenuates stress-induced NO increase in the CNS, and induces antidepressant-like effects (Joca \& Guimarães, 2006; Montezuma et al., 2012; Hiroaki-Sato et al., 2014; Stanquini et al., 2017). Accumulating evidence indicates that NO-induced effects might be related to its ability to regulate BDNF-TrkB signaling and neuronal plasticity in the mature brain (Biojone et al., 2015).

NO can also regulate activity and expression of chromatin-modifying enzymes, thus posing an important role for NO in modulating epigenetic mechanisms (Campos et al., 2007; Katayama et al., 2009; Vasudevan et al., 2016; Socco et al., 2017). However, it is not known if NO release during exposure to stress increases the DNMTs expression and DNA methylation in the brain.

Thus, we hypothesized that the antidepressant-like effect of NOS inhibitors is associated with a decrease in DNA methylation. To this aim, we assessed the effect of NOS inhibitors in the expression of DNA 
methyltransferases in cultured hippocampal cells exposed to stress mediators and rats exposed to inescapable foot shocks.

\section{Methods}

\subsection{Animals}

Male Wistar rats (8 weeks old, weighing 270-300g) were obtained from the animal facility of the University of São Paulo/USP Ribeirão Preto. The animals were kept undisturbed for one week before the beginning of the experiments, except for regular cage cleaning, in groups of four per cage $(41 \times 34 \times 16 \mathrm{~cm})$ at $24 \pm 1{ }^{\circ} \mathrm{C}$ under standard laboratory conditions (12h light/12h dark, lights on at 06:30 a.m.) with free access to food and water. During the experimental procedure, the animals were kept isolated $(30 \mathrm{x} 20 \mathrm{x} 13 \mathrm{~cm})$ with free access to food and water (Sales \& Joca, 2018). The total number of animals used in this study were 170. All procedures were conducted in accordance with the Brazilian Council for Animal Experimentation (COBEA), which comply with international laws and policies. The protocols were approved by the local Ethical Committee (protocol number 15.1.285.60.5.), and all efforts were made to minimize animal suffering and to reduce the number of animals used. The experiments were conducted between 08:00-17:00 with randomization of the experimental groups throughout the day.

\subsection{Pharmacological Treatment}

The animals received intraperitoneal injections of aminoguanidine - AMG (30mg/kg, Sigma-Aldrich (\#396494), St. Louis, MO, USA), 7-nitroindazole - 7NI (60mg/kg, Sigma-Aldrich (\#N7778), St. Louis, MO, USA) or vehicle ( $\mathrm{NaCl} 0.9 \%$ for AMG; polyethylene glycol and $\mathrm{NaCl} 0.9 \%-1: 1$ - for 7-NI). The drugs were injected immediately after the LH pretest session and repeated once a day for 7 days. The last injection was performed $1 \mathrm{~h}$ before the behavioral test or euthanasia. The dose and schedule of treatment were based in literature (Joca et al., 2003; Stanquini et al., 2017; Sales \& Joca, 2018). For in vitro experiments, the nNOS inhibitor $\mathrm{n}^{\omega}$-propyl-L-arginine (NPA, 100nM, Sigma-Aldrich, \#SML2341) was administered 30 minutes before the stimulus with NMDA (30 $\mu \mathrm{M}$ for or 1h; Sigma-Aldrich, \#M3262), dexamethasone $(1 \mu \mathrm{M}$ for $1 \mathrm{~h}$ or $24 \mathrm{~h}$, Sigma-Aldrich, \#D4902) or L-arginine (0.5mM for 1h, Sigma-Aldrich, \#A5006). All concentrations and schedules of treatment were based on previous studies in the literature (Sandoval et al., 2011; Anacker et al., 2013; Xiong et al., 2014).

\subsection{Learned helplessness test}

The learned helplessness (LH) model is based on the exposure to inescapable footshocks, which leads to increased number of escape failures in a later learning associative task (Maier \& Watkins, 2005; Maier \& Seligman, 2016). Increased circulating glucocorticoid levels and glutamate release, as well as increased synthesis and release of nitric oxide (NO) have also been described in this paradigm (Prast \& Philippu, 2001; Joca et al., 2003; Popoli et al., 2011; Nava et al., 2017; Stanquini et al., 2017; Sales \& Joca, 2018). Repeated treatment with antidepressants (Joca et al., 2003) and nNOS inhibitors (Stanquini et al., 2017) attenuates the number of escape failures during the LH test, considered a reliable antidepressant-like effect.

The behavioral experiment consisted of two sessions (pretest and test), as previously described (Stanquini et al., 2017). During the pretest, the animals were randomly assigned to one of the following conditions: stressed group (IS - inescapable shocks) or habituated group (hab - no-shocks). The animals in the IS group were individually placed into the automated shuttle boxes $(307 \times 333 \times 540 \mathrm{~mm}$, Model EP 11 , Insight Scientific Equipment), with two compartments of equal size separated by a wall with a central open door (communicating the two compartments), and forty inescapable foot shocks $(0.4 \mathrm{~mA}, 10$ s duration) were given in a variable schedule with a mean interval of 60s (range from 30-90s) through the metal grid floor. The 
habituated group was exposed to the same apparatus for $30 \mathrm{~min}$, but no shock was delivered. After six days, both groups were submitted to the test session $(\mathrm{T})$. The test consisted of 30 escapable foot shocks $(0.4 \mathrm{~mA}, 10 \mathrm{~s}$ duration, 30-90s interval), which were preceded by a tone $(60 \mathrm{~dB}, 670 \mathrm{~Hz})$ that started $5 \mathrm{~s}$ before each shock and lasted until its end. Animals could prevent or interrupt the shock delivery by either crossing to the opposite side of the box during sound presentation (avoidance) or by crossing during its presentation (escape). The absence of any of these behaviors was considered escape failure. The number of crossings during the intervals between shocks, in the test session, was used as an index of locomotor activity (Geoffroy \& Christensen, 1993; Stanquini et al., 2017; Sales \& Joca, 2018).

\subsection{Cell culture}

Primary cultures of hippocampal cells from E17-E18 rat embryos were prepared as detailed in literature (Sahu et al., 2019). Briefly, hippocampus of E18 rat embryos were dissected and suspended cells were seeded on poly-L-lysine coated 24 -well plates $\left(250,000\right.$ cells/well, $\left.1.9 \mathrm{~cm}^{2}\right)$ in Neurobasal medium supplemented with B27, $1 \%$ penicillin/streptomycin, $1 \%$ L-glutamine. The medium was changed weekly, and the cells were treated and lysated between DIV 8-10.

\subsection{Gene expression analysis by quantitative real-time RT-PCR (RT-qPCR).}

Total RNA was extracted using Trizol ${ }^{\circledR}$ reagent (from Life technologies) according to manufacturer's instruction and quantified by spectrophotometer (Nanodrop 2000C spectrophotometer, Thermo Scientific). The cDNA was synthesized from $2 \mu \mathrm{g}$ of total RNA using Maxima first strand cDNA synthesis kit for RT-qPCR with dsDNase (Thermo Scientific) according to the manufacturer's instruction. Two controls of reaction were performed: reverse transcriptase minus (RT-) negative control, which contains all reagents for the reverse transcription reaction except the Maxima Enzyme Mix; and the non-template control (NTC), which contains all reagents for the reverse transcription reaction except the RNA template. The primers used to amplify specific cDNA transcripts are listed in table 1 (Karpova et al., 2010). Quantitative PCR was performed using Thermo Scientific Maxima SYBR Green qPCR Master Mix (2x). The reaction was done in a volume of $20 \mu 1(10 \mu 1$ SYBR Green Master Mix 2x; $4 \mu \mathrm{l}$ water - nuclease free; $0,5 \mu 1$ of primers (forward and reverser, $0.25 \mu \mathrm{M}$, final concentration) and $5 \mu 1$ of cDNA. The DNA amplification reaction was assayed in triplicates in the Bio-Rad C1000TM Thermal Cycle. The qPCR condition was set at $95^{\circ} \mathrm{C}$ for $10 \mathrm{~min}$ (denaturation) and 44 cycles at $95^{\circ} \mathrm{C}$ $15 \mathrm{~s}$ (denaturation); temperature of annealing (mT), depending on the primers used for $30 \mathrm{~s}$ and $72^{\circ} \mathrm{C}$ for $30 \mathrm{~s}$ (extension). At the end of the cycling protocol, a melting-curve analysis was included, which showed a single peak in all experiments. Hprtl gene expression was not modified by any of the treatments, and it was then chosen as housekeeping gene for later relative quantitations. The relative expression levels for each target gene was calculated by the $2^{-(\Delta \Delta C T)}$ method (Livak \& Schmittgen, 2001). The results were expressed as $\%$ from vehicle-treated groups.

\section{Table 1. Sequence of primers}

\begin{tabular}{|l|l|l|}
\hline Gene & Primers & $\mathrm{mT}\left({ }^{\circ} \mathrm{C}\right)$ \\
\hline DNMT1 & $\begin{array}{l}\text { FWD: 5'-TAGAGCGTTCATGGGGCTG-3' } \\
\text { REV: 5'-GGTGTTGTCTACCGAGTGGG-3' }\end{array}$ & 60 \\
\hline DNMT3a & $\begin{array}{l}\text { FWD: 5'-ACAGAGAAACCCAACGTCAAC-3' } \\
\text { REV: 5'-GGCTCCCACATGAGATACAAA-3' }\end{array}$ & 63 \\
\hline DNMT3b & $\begin{array}{l}\text { FWD: 5'-GAACAAACTCAAGGGACCAAAC-3' } \\
\text { REV: 5'-GCCAGGAAGACTTAACCCATAA-3' }\end{array}$ & 63 \\
\hline Hprt1 & $\begin{array}{l}\text { FWD: 5'-GCAGACTTGCTTTCCTTGG-3' } \\
\text { REV: 5'-CGAGAGGTCCTTTTCACCAG-3' }\end{array}$ & 60 \\
\hline
\end{tabular}




\subsection{Experimental Design}

\subsubsection{NMDA-nNOS/NO signalling effects in DNA methyltransferase mRNA.}

Hippocampal cell cultures (DIV 8-10) were pre-treated with NPA (100nM) followed, 30min later, by NMDA $(1 \mu \mathrm{M})$. One hour after, mRNA was extracted and the DNMT1, DNMT3a and DNMT3b mRNA were determined by RT-qPCR as described. Another batch of cells was pre-treated with NPA (100nM) followed by L-arginine $(0.5 \mathrm{mM})$. The mRNA was extracted, one hour after the last drugs administration and the DNMT3b mRNA was assessed by RT-pPCR.

\subsubsection{Effect of dexamethasone in DNMT3b mRNA expression.}

In another experimental set, hippocampal cell cultures (DIV 8-10) were pre-treated with NPA (100nM) followed by dexamethasone $(1 \mu \mathrm{M})$. One or 24 hours after the last drug administration the mRNA was extracted as described and the DNMT3b mRNA were determined by RT-qPCR.

\subsubsection{Antidepressant-like effect of NOS inhibitors.}

The behavioral effects of NOS inhibitors were assessed using the learned helplessness paradigm as described. The drug effect was evaluated in the stressed group (exposed to inescapable foot shocks) and the habituated group (exposed to shuttle box without foot shocks). The experimental number for each group was based as calculated in our previous publication (Stanquini et al., 2017). Each experimental session included at least 2 animals of each treatment group and the experiment was repeated 5-6 times, always including animals of the different treatment conditions. Immediately after PT session the rats were injected with AMG (30 mg/kg, ip) or vehicle (saline $0.9 \%$, ip) and once a day for the following 6 days. The last injection was performed $1 \mathrm{~h}$ before the behavioral test. Another group of rats was treated with $7 \mathrm{NI}(60 \mathrm{mg} / \mathrm{kg}$, ip) or vehicle (polyethylene glycol and $\mathrm{NaCl} 0.9 \%-1: 1$, ip) under the same protocol described. On the seventh day, the number of failures, latency to escape and inter-trail crossing were automated assessed.

\subsubsection{Increase of DNMT3b mRNA in the hippocampus of rats exposed to inescapable foot shocks.}

Based on the in vitro results, an independent group of animals were exposed to inescapable footshock (stressed group) and euthanized $1 \mathrm{~h}, 24 \mathrm{~h}$ or 7 days later for mRNA extraction from the hippocampus (vHPC and dHPC) as described, and the DNMT3b mRNA was determined. In another set of experiments, the animals were treated with AMG or 7NI immediately after PT session, followed by euthanizing $1 \mathrm{~h}$ after the drug administration. Another other experimental group was exposed to two injections, the first immediately and the second $23 \mathrm{~h}$ after the PT, followed by euthanasia $1 \mathrm{~h}$ after the last drug administration. The RNA extraction and RT-qPCR were evaluated as described.

\subsection{Statistical analysis}

Discrete variables, such as the number of failures, avoidance, and intertrial crossings in LH experiments were analysed by non-parametric tests (Kruskal-Wallis), followed by Dunn's multiple comparison whenever appropriate. The in vitro experiments were analyzed by two-way ANOVA followed by Bonferroni's test, with stress and pharmacological treatment as main factors, or Student's t-test. Results of RT-PCR from in vivo experiments were analyzed by one-way ANOVA followed by Newman-Keuls' test. P values below 0.05 were considered statistically significant. All data used in the present manuscript is available under CC-BY license in FigShare (DOI:10.6084/m9.figshare.12424349). 


\section{Results}

\subsection{NOS inhibitor NPA attenuated DNMT3b increase in hippocampal primary cell culture challenged with NMDA or dexamethasone.}

To investigate the molecular mechanisms associated with NO effects on DNA methylation in vitro, we used hippocampal cell cultures. In order to simulate stress effects on the cells, we used the glucocorticoid receptor agonist dexamethasone, or NMDA to activate NMDAr. Previous studies indicate stress triggers increased glutamate release in the brain and the activation of NMDAr and nNOS/NO signaling in hippocampus (Popoli et al., 2011; Sandoval et al., 2011; Musazzi et al., 2013; Joca et al., 2015; Wegener \& Joca, 2016). Thus, we exposed cultured hippocampal cells to NOS inhibitor NPA (100nM/30min), followed by NMDA $(30 \mu \mathrm{M} / 1 \mathrm{~h})$, figure $1 \mathrm{~A}$. The pretreatment with NPA $100 \mathrm{nM}$ prevented NMDA-induced DNMT3b mRNA increase (interaction, $\mathrm{F}_{1,32}=4.851, \mathrm{p}=0.03, \mathrm{~N}=9$; figure $1 \mathrm{~B}$ ). However, the DNMT1 (interaction, $\mathrm{F}_{1,20}=0.02$, $\mathrm{p}=0.90, \mathrm{~N}=6$; figure 1D) or DNMT3a (interaction, $\mathrm{F}_{1,20}=0.08, \mathrm{p}=0.78, \mathrm{~N}=6$; figure 1E) mRNA amount were not affected by the NMDA or NPA treatments. To evaluate if nNOS/NO activation could directly induce an increase of DNMT3b mRNA in hippocampal primary cell culture, we assayed the DNMT3b mRNA after the treatment with the NOS substrate L-arginine $(0.5 \mathrm{mM} / 1 \mathrm{~h}$ ) (Xiong et al., 2014). L-arginine increased the DNMT3b mRNA, which was attenuated by NPA pretreatment (interaction, $\mathrm{F}_{1,20}=13.35, \mathrm{p}=0.0009, \mathrm{~N}=6$; figure 1C).

Based on the role of corticosterone/dexamethasone on the activation of NMDA receptors in hippocampus (Takahashi et al., 2002), we also tested whether dexamethasone could induce similar changes on DNMTs mRNA amount in vitro. As expected, dexamethasone $(1 \mu \mathrm{M} / 24 \mathrm{~h})$ increased DNMT3b mRNA, which was attenuated by pretreatment with NPA $(100 \mathrm{nM} / 30 \mathrm{~min})$ (interaction: $\mathrm{F}_{1,20}=20.29 ; \mathrm{p}=0.0002, \mathrm{~N}=6$; figure $2 \mathrm{C})$. However, the DNMT3b mRNA was not changed after only $1 \mathrm{~h}$ incubation with dexamethasone $\left(\mathrm{F}_{1,8}=\right.$ $0.1225 ; \mathrm{p}=0.74, \mathrm{~N}=3$; figure $2 \mathrm{~B}$ ) or by pretreatment with NPA (interaction: $\mathrm{F}_{1,8}=1.066 ; \mathrm{p}=0.33, \mathrm{~N}=3$; figure 2B). Moreover, the DNMT1 ( $1 \mathrm{~h}: \mathrm{t}=1.644, \mathrm{df}=4, \mathrm{p}=0.175$; figure $2 \mathrm{D}$ and $24 \mathrm{~h}: \mathrm{t}=1.122, \mathrm{df}=10, \mathrm{p}=0.288$; figure $2 \mathrm{~F}$ ) or DNMT3a ( $\mathrm{h}: \mathrm{t}=0.55, \mathrm{df}=4, \mathrm{p}=0.61$; figure $2 \mathrm{E}$ and $24 \mathrm{~h}: \mathrm{t}=0.35, \mathrm{df}=10, \mathrm{p}=0,73$; figure $2 \mathrm{G}$ ) mRNA did not change after dexamethasone treatment.
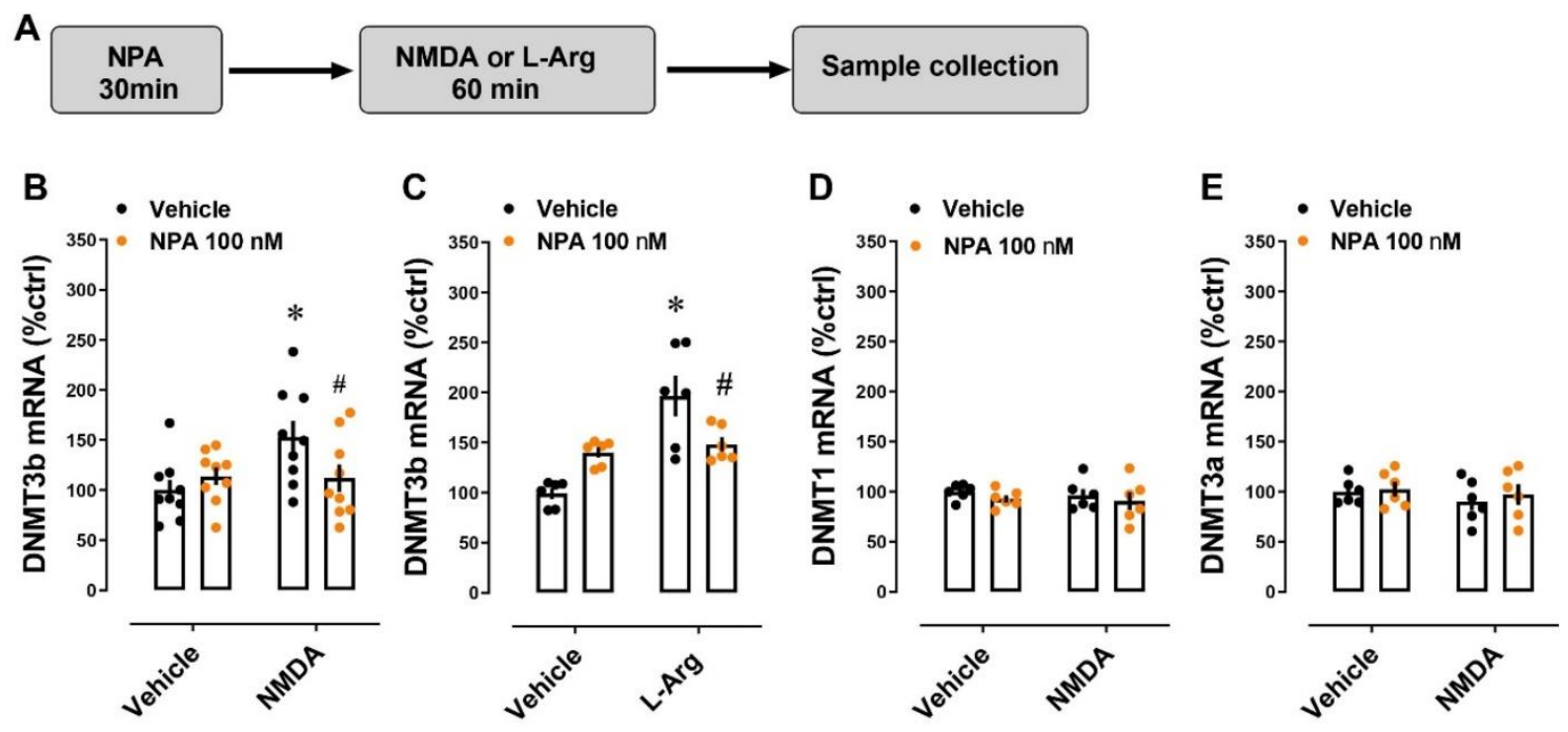

Figure 1: nNOS inhibitor NPA prevented the increase in DNMT3b mRNA in neuronal hippocampal cell culture challenged with NMDA or L-arginine: (A) Timeline of experimental approach. The previous treatment with NPA (100nM/30min) attenuates the increase of DNMT3b mRNA induced by (B) NMDA $(30 \mu \mathrm{M} / 1 \mathrm{~h})$ or $(\mathrm{C}) \mathrm{L}$-arginine $(0.5 \mathrm{mM} / 1 \mathrm{~h})$. No interaction was observed for the amount of (D) DNMT1, (E) DNMT3a after challenge with NMDA, N=6-9. Each column represents the mean \pm SEM. *p<0.05 from vehicle/vehicle group; $\# \mathrm{p}<0.05$ from the NMDA/vehicle or L-Arg/vehicle groups. 


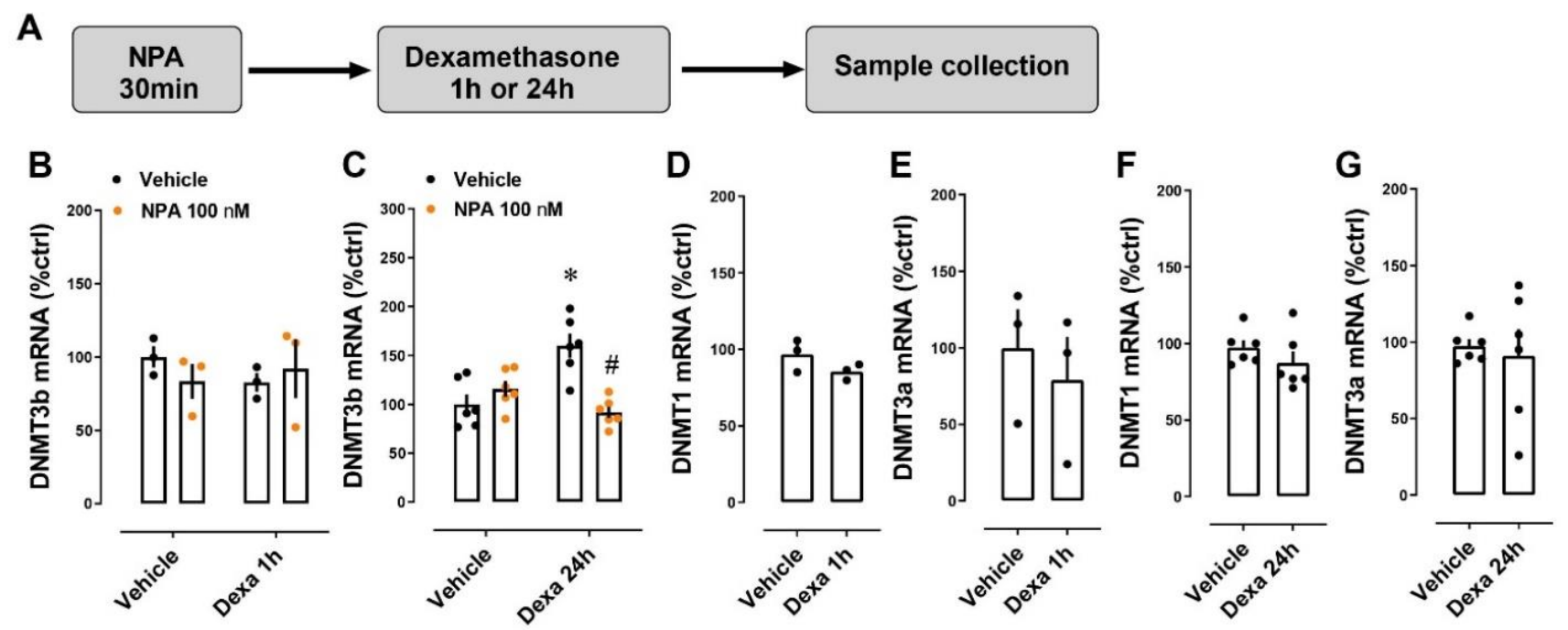

Figure 2: nNOS inhibitor modulated the DNMT3b mRNA expression in hippocampal cell culture challenged with dexamethasone: (A) Timeline of experimental approach. Relative amount of DNMT3b (B and C), DNMT1 (D and F), and DNMT3a $(\mathrm{E}$ and G) mRNA after pretreatment with NPA $(100 \mathrm{nM} / 30 \mathrm{~min})$ followed by dexamethasone $(1 \mu \mathrm{M})$ for $1 \mathrm{~h}$ or $24 \mathrm{~h}, \mathrm{~N}=3-6$. Each column represents the mean \pm SEM. $* \mathrm{p}<0.05$ from the vehicle/vehicle group; $\# \mathrm{p}<0.05$ from the dexamethasone/vehicle group.

\subsection{NOS inhibitors attenuated the depressive-like behavior and the increase of DNMT3b mRNA in rats submitted to the $\mathbf{L H}$.}

Repeated treatment with AMG (Kruskal-Wallis, $\mathrm{H}=25.64$, $\mathrm{df}=3$; $\mathrm{p}=0.03$; $\mathrm{N}=11-13$ ) or 7NI (KruskalWallis, $\mathrm{H}(3)=15.65, \mathrm{df}=3 ; \mathrm{p}=0.02 ; \mathrm{N}=10-13)$, figure $3 \mathrm{~B}-\mathrm{C}$, attenuated the increase in escape failures, as well the latency time to escape/avoid shocks (AMG, interaction: $\mathrm{F}_{1,45}=4.924 ; \mathrm{p}=0.03 ; \mathrm{N}=11-13$, figure 3D or 7NI, interaction: $\mathrm{F}_{1,40}=6.45 ; \mathrm{p}=0.01 ; \mathrm{N}=10-13$, figure $3 \mathrm{E}$ ) in rats submitted to $\mathrm{LH}$ paradigm. Neither stress nor pharmacological treatment changed the locomotor activity assessed by intertrial crossing $(\mathrm{H}=1.664, \mathrm{df}=3$; $\mathrm{p}=$ $0.99 ; \mathrm{N}=11-13$ and $\mathrm{H}=2.731, \mathrm{df}=3 ; \mathrm{p}=0.99 ; \mathrm{N}=10-13$, for $\mathrm{AMG}$ and 7-NI, respectively; figure $3 \mathrm{~F}$ and $3 \mathrm{G})$.

In order to assess the effect of inescapable and uncontrollable foot shock on the DNMT3b mRNA in the hippocampus, we assayed the mRNA levels at $1 \mathrm{~h}, 24 \mathrm{~h}$ and 7 days after the pretest session. Exposure to inescapable and uncontrollable footshocks in pretest session induced an increase of DNMT3b mRNA in dHPC $\left(\mathrm{F}_{3,28}=17.16 ; \mathrm{p}=0.0001, \mathrm{~N}=8\right.$, figure $\left.3 \mathrm{H}\right)$ and in $\operatorname{vHPC}\left(\mathrm{F}_{3,28}=5.269 ; \mathrm{p}=0.005, \mathrm{~N}=8\right.$, figure $\left.3 \mathrm{I}\right)$ after $1 \mathrm{~h}$ and 24h. However, in both hippocampal regions, the amount of DNMT3b mRNA returned to basal 7 days after exposure to the shocks (figure 3H,I). In dHPC, the treatment with both NOS inhibitors (AMG or 7NI) prevented the increase of DNMT3b mRNA at $1 \mathrm{~h}\left(\mathrm{~F}_{3,18}=10.06 ; \mathrm{p}=0.0004, \mathrm{~N}=5-6\right.$; figure $\left.3 \mathrm{~J}\right)$ and $24 \mathrm{~h}\left(\mathrm{~F}_{3,18}=6.302 ; \mathrm{p}=\right.$ 0.004, N= 5-6; figure 3L). On the other hand, in vHPC, the treatment with AMG attenuated the stress-induced increase of DNMT3b mRNA at $24 \mathrm{~h}\left(\mathrm{~F}_{3,20}=7.635 ; \mathrm{p}=0.001, \mathrm{~N}=6\right.$; figure $\left.3 \mathrm{~L}\right)$, but did not change the mRNA quantity at $1 \mathrm{~h}\left(\mathrm{~F}_{3,19}=4.386 ; \mathrm{p}=0.02, \mathrm{~N}=5-6\right.$; figure $\left.3 \mathrm{~K}\right)$. In both time points assayed ( $1 \mathrm{~h}$ and $\left.24 \mathrm{~h}\right)$, the treatment with 7NI did not inhibit the increase of DNMT3b mRNA ( $1 \mathrm{~h}: \mathrm{F}_{3,19}=4.386 ; \mathrm{p}=0.02, \mathrm{~N}=6$ and 24h: $\mathrm{F}_{3,20}=7.635$; $\mathrm{p}=0.001, \mathrm{~N}=6$; figure $3 \mathrm{~J}, \mathrm{~K}$ ). 

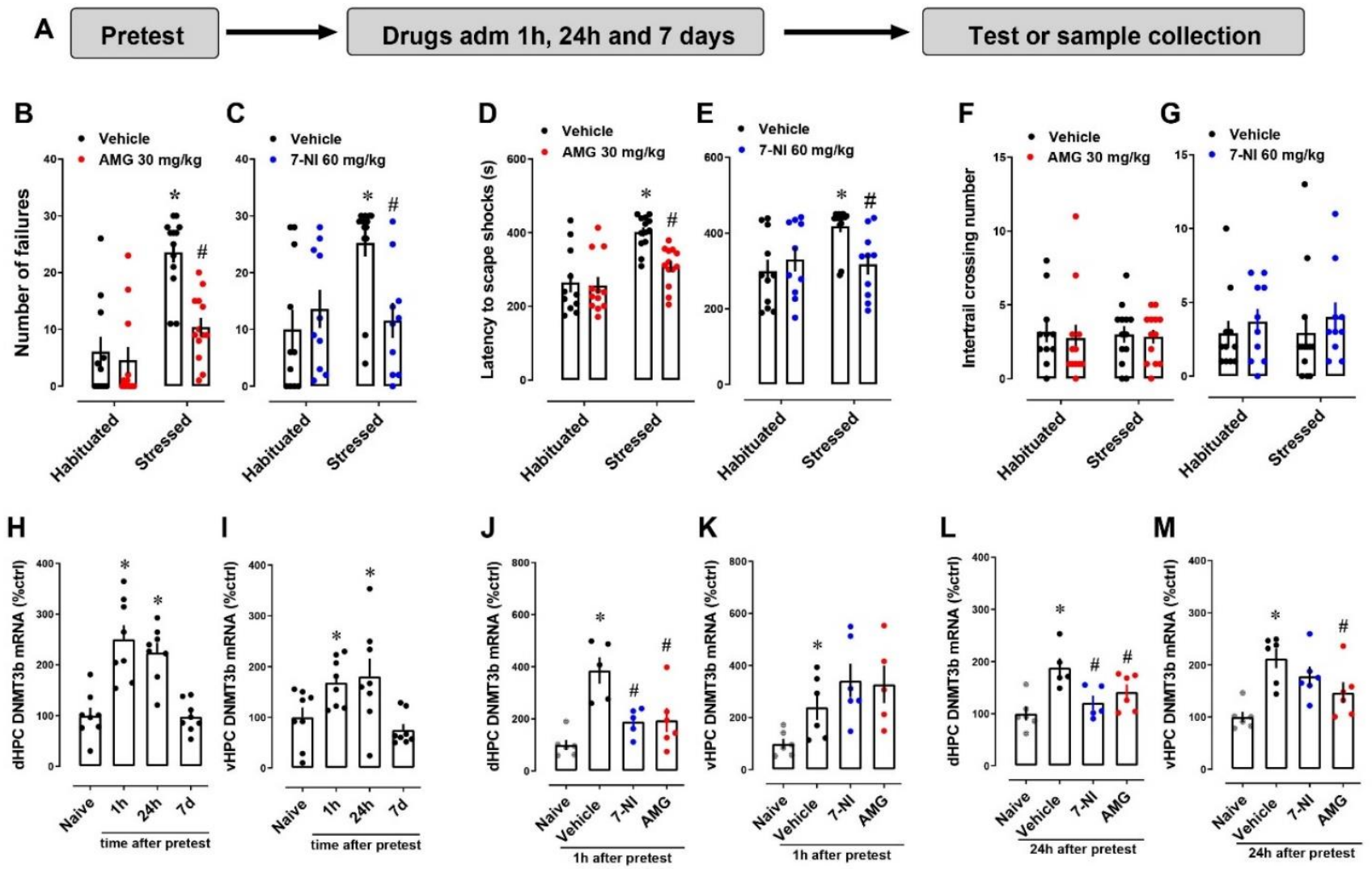

Figure 3: Antidepressant effect of NOS inhibitors is associated with a decrease in DNMT3b mRNA in the hippocampus. (A) Timeline of experimental approach. The animals were submitted to inescapable foot shocks (IS, stressed) or habituated (hab, nonstressed) in a shuttle-box. Immediately after IS, the rats were treated with AMG $(30 \mathrm{mg} / \mathrm{kg}) ; 7-\mathrm{NI}(60 \mathrm{mg} / \mathrm{kg})$ or vehicle, once a day for up to 7 days $(\mathrm{N}=13-14)$. One hour after the last injection, the rats were submitted to the $\mathrm{LH}$ test session or euthanized for hippocampus dissection. The administration of AMG or 7-NI attenuated the effect of IS in (B and C) number of failures, (D and E) latency time to escape/avoid shocks but no alterations were observed in ( $\mathrm{F}$ and $\mathrm{G})$ locomotor activity assessed by intertrail crossing. Independent groups of animals were submitted to IS and the brains were dissected after $1 \mathrm{~h}, 24 \mathrm{~h}$ or 7 days ( $\mathrm{H}$ and I), N=6-8. To assess the effect of NOS inhibitor in DNMT3b mRNA amount, immediately after pretest session (IS) the rats were treated with one i.p injection (1h, J and K) or 2 i.p, injections, one immediately after pretest session and another $1 \mathrm{~h}$ before the brain dissection $(24 \mathrm{~h}, \mathrm{~L}$ and $\mathrm{M})$. Data are expressed as mean \pm S.E.M. * $\mathrm{p}<0.05$ from hab/vehicle or naive groups; \#p< 0.05 from stressed/vehicle group. PT: pretest; IS: inescapable footshock; Hab: habituated, non-stressed; AMG: aminoguanidine; 7-NI: 7-nitroindazole. 


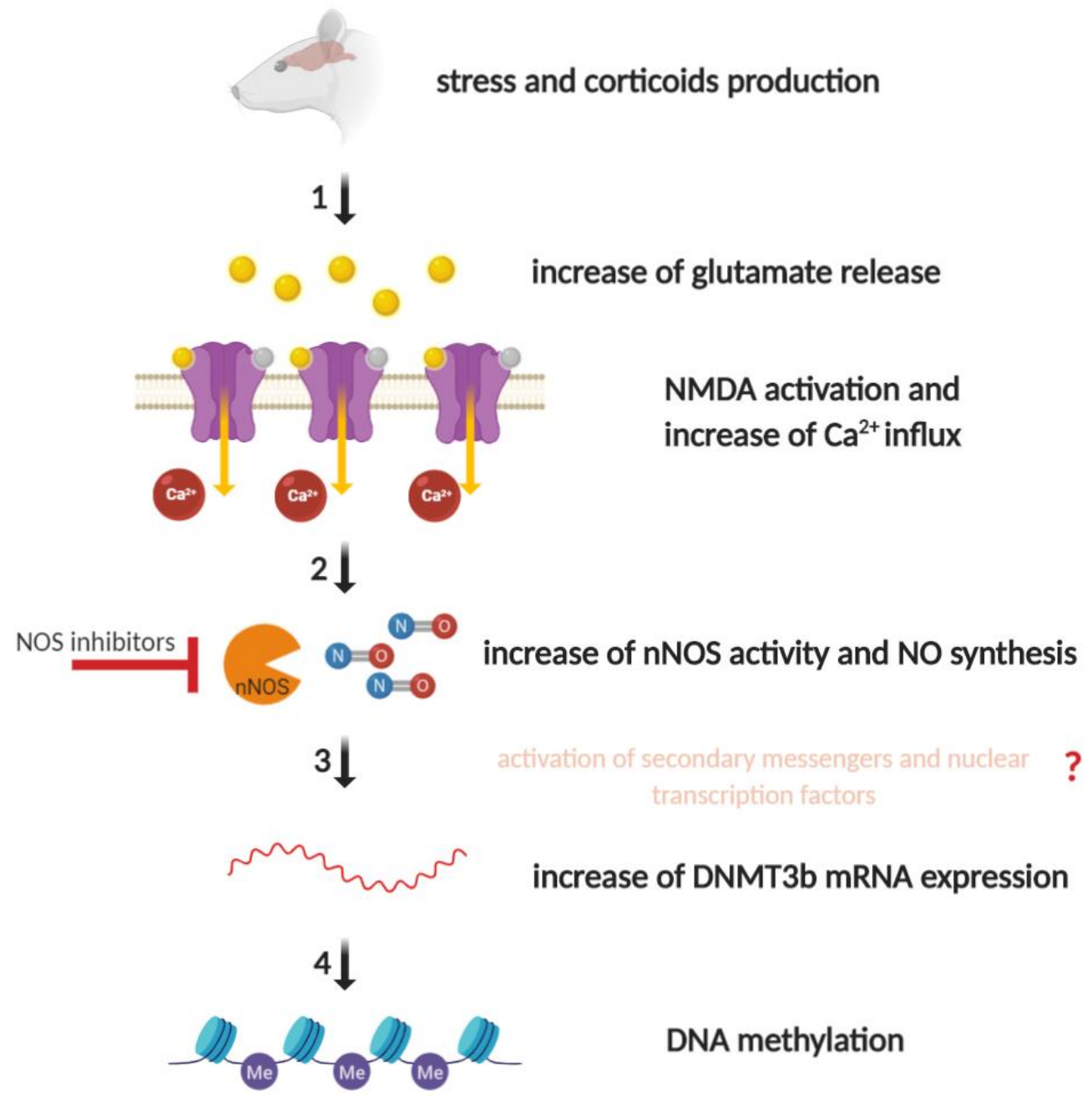

Figure 4: Summary of the hypothetical role of NO in DNA methylation induced by stress. The stress induced by uncontrollable and unpredictable foot shocks increases the release of glutamate in the hippocampus (1), which activates NMDA receptors and increases calcium influx. In hippocampus neurons, the increase of $\mathrm{Ca}^{2+}$ influx promotes nNOS activation and NO synthesis, which could increase the activity of secondary messengers and nuclear transcription factors, ultimately leading to increased DNMT3b expression (2). The NOS inhibitors mitigated the increase of DNMT3b during stress, which may prevent the DNA methylation in the hippocampus of rats (3 and 4).

\section{Discussion}

The present study describes the effect of NOS inhibitors on DNMT3b mRNA expression induced by stress. Challenging cultured hippocampal neurons with mediators of the stress response (NMDAr agonist or the glucocorticoid dexamethasone) increased DNMT3b mRNA expression. Rats exposed to inescapable and uncontrollable foot shocks displayed learned helplessness behavior, characterized by an increase in the number of failures to escape foot shocks in the test session. Such phenotype was associated with increased DNMT3b mRNA expression in the hippocampus, and in both in vitro and in vivo approaches, the pre-treatment with NOS inhibitors attenuated the stress-induced increase in DNMT3b mRNA expression. 
Acute stress triggers a complex response involving the synthesis and release of mediators such as corticoids, glutamate and NO, which can acutely alter gene expression as well as induce long-term molecular and behavioral changes (Popoli et al., 2011; Joca et al., 2019). The increase in NO and/or reactive oxygen species (ROS) can directly impact gene expression (Riccio et al., 2006; Lee et al., 2009; Nott \& Riccio, 2009). For instance, oxidative stress can increase the activity of specificity protein $(\mathrm{Sp})$, a transcription factor involved in DNMT expression (Ryu et al., 2003; Jinawath et al., 2005; Lin \& Wang, 2014; Chuang et al., 2017), and NO facilitates cGMP, PKG, and ERK signaling cascades, involved in the activation of CREB, which in turn modulates the expression of several genes (Lu et al., 1999; Gallo \& Iadecola, 2011).

Little attention has been given to the role of NO on DNA methylation. Some sparse evidence indicates that cellular stress increases NO production, followed by DNMT3b and DNMT1 expression (Campos et al., 2007; Huang et al., 2012). Also, the NO donor (Sodium Nitroprusside - SNP) increases the DNMT activity and decreases fragile X retardation 1 (FMR1) gene expression in Jurkat T cell (Hmadcha et al., 1999). We observed that NPA prevented the increase in DNMT3b levels by NMDA or L-arginine in cultured hippocampal cells. Corroborating these findings, the non-selective NOS inhibitor (L-NAME) attenuates the DNMT expression, and the levels of 5-Methylcytosine, indicative of global DNA methylation, in melanoma cells under stress (Campos et al., 2007). However, in our conditions, NMDA significantly increased DNMT3b mRNA, but not DNMT3a or DNMT1 mRNA.

Increased activation of HPA-axis and corticoid receptors in the brain is involved in genomic and nongenomic changes induced by stress (McEwen et al., 2016; van Bodegom et al., 2017). As described above, 24h dexamethasone treatment in hippocampal cell culture increased DNMT3b mRNA levels, which was prevented by NPA. In line with our data, dexamethasone treatment increases DNA methylation in the promoter region of the crh gene. Such mechanism is associated with the formation of a repressor complex consisting of glucocorticoid receptor (GR) and DNMT3b in rat hypothalamic IVB cells (Sharma et al., 2013). Also, cultured primary cortical neurons treated with corticosterone $(10 \mu \mathrm{M})$ show increased levels of DNMT1, DNMT3a and DNMT3b mRNA, which are abolished by co-treatment with GR antagonist mifepristone $(20 \mu \mathrm{M})(\mathrm{Urb}$ et al., 2019). Thus, it is possible to assume that the genomic effects induced by GR activation may lead to increased DNMTs expression and DNA methylation in neurons. In addition, membrane glucocorticoid receptors facilitate and sustain calcium influx through NMDAr, resulting in $\mathrm{Ca}^{2+}$ neurotoxicity in hippocampal neurons (Takahashi et al., 2002). Together, these data suggest that DNMT mRNA expression is stimulated by stress mediators, and NO is a key mediator of DNMT3b mRNA expression triggered by glucocorticoids and NMDA-NOS/NO signaling.

NO has been involved in many signaling pathways related to stress and MDD, as well as to the antidepressant activity of classical drugs (Wegener et al., 2003; Joca \& Guimarães, 2006; Wegener \& Volke, 2010; Hiroaki-Sato et al., 2014). Corroborating the results from the present study, pharmacological inhibition of NOS induces antidepressant-like effects in the learned helplessness paradigm (Stanquini et al., 2017) and other models, such as forced swimming test (Ferreira et al., 2012; Montezuma et al., 2012; Sales et al., 2017) and unpredictable chronic stress (Yazir et al., 2012). Furthermore, activation and expression levels of NOS is attenuated by treatment with antidepressant drugs (Finkel et al., 1996; Wegener et al., 2003; Dhir \& Kulkarni, 2007, 2011; Zomkowski et al., 2010; Zhou et al., 2011; Bollinger et al., 2017). Accordingly, MDD patients treated with selective serotonin reuptake inhibitors (SSRI) present a decrease of nitrate levels in the blood (Finkel et al., 1996), and rodents treated with SSRIs exhibit a reduction in the NOS activity in the brain (Krass et al., 2011).

Here, the repeated administration of NOS inhibitors counteracted the behavioral effects of uncontrollable stress, similarly to the treatment with classical antidepressant imipramine (Stanquini et al., 2017). Moreover, the behavioral effects of NOS inhibitors were associated with attenuation of the DNMT3b mRNA 
expression, which peaked in the hippocampus from $1 \mathrm{~h}$ to $24 \mathrm{~h}$ after stress. To our knowledge, this is the first evidence that the antidepressant-like effect of NOS inhibitors could be associated with the attenuation of stressinduced DNMT3b/DNA methylation.

Although acute treatment with NOS inhibitors is not sufficient to rescue the behavior change in LH (Stanquini et al., 2017), some studies suggest that, at the molecular level, acute administration of NOS inhibitors in rodents can modulate transcription factors, as well as gene expression (Joca et al., 2007; Nott \& Riccio, 2009; Zhou et al., 2011). Our data indicates that the pharmacological effect of AMG or 7NI on DNMT3b mRNA expression could be the result of acute inhibition of transcription factors activity mediated by NO in the hippocampus of rats exposed to inescapable foot shocks. Thus, the antidepressant effect induced by NOS inhibition, i.e. the facilitated adaptation to stress, could be the long-term consequence of the inhibition of DNMT3b/DNA methylation.

The hippocampus is highly susceptible to the effects of stress, seen as impaired function and changes in gene expression (Crosio et al., 2003; Gray et al., 2014). Previous data show that pharmacological or genetic inhibition of DNMT promotes antidepressant phenotype in rodents (Sales et al., 2011; Morris et al., 2016; Sales \& Joca, 2016). Direct inhibition of DNMTs into the dorsal hippocampus induces similar effects in rats exposed to stress (Sales et al., 2011), thus posing a central role for epigenetic mechanisms in this structure during stress. Also, stressed animals show an increase of global DNA methylation in HPC (Doherty et al., 2016; Sales \& Joca, 2016), which is attenuated by antidepressant drugs treatment (Sales \& Joca, 2016). Thus, it is possible to consider that, during stress, activation of corticoid receptors facilitates glutamate release and NMDA activation in the hippocampus, ultimately leading to NO synthesis. However, it is unclear how NO could regulate DNMT3b expression, but it is plausible to consider that it involves nuclear transcription factors, such as specificity protein $\mathrm{Sp} 1, \mathrm{Sp} 3$ or $\mathrm{CREB}$, as proposed in figure 4. We speculate that the antidepressant-like effect of NOS inhibitors in rats exposed to LH test is associated with inhibition of mechanisms that control DNMT3b mRNA expression in hippocampus neurons.

Fanselow and Dong (Fanselow \& Dong, 2010) published a comprehensive review about the behavioral, anatomical and patterns of gene expression studies showing a functional segmentation of hippocampus in three compartments (dorsal, intermediate, and ventral). At the molecular level, gene expression in the dHPC correlates with cortical regions involved in information processing (cognitive function), while in the vHPC this expression correlates with regions involved in the control of emotion and response to stress (amygdala and hypothalamus). According to these authors, the exact boundaries between these subregions are not clear and that the intermediate portion of HPC have distinct neuronal connectivity patterns, which influence gene expression (Fanselow \& Dong, 2010). Furthermore, dHPC and vHPC are impacted differently by acute or chronic stress at genomic and proteomic level, as well as by pharmacological treatment (Diniz et al., 2016; Floriou-Servou et al., 2018). Data from our group showed that acute stress (FST) increases the phosphorylation of nNOS in dHPC, but not in vHPC of rats (Diniz et al., 2016). Interestingly, the local administration in dHPC of the nNOS inhibitor NPA immediately after the pretest session in FST, or $1 \mathrm{~h}$ before the test session, decreases the immobility time in FST. On the other hand, in the vHPC, this compound decreases the immobility time only when infused $1 \mathrm{~h}$ before the test (Diniz et al., 2016). These data are in line with the results from the present study, where both NOS inhibitors (AMG or 7NI) treatment decreased the DNMT3b mRNA expression on dHPC at $1 \mathrm{~h}$ (one injection) and $24 \mathrm{~h}$ (two injection) after stress. In vHPC, only two injections (1h and 23h after stress) of AMG, significantly decrease the DNMT3b mRNA expression. Together, these results indicate that dHPC and vHPC have different sensitivity to stress and to the pharmacological effect of NOS inhibitors.

In conclusion, we showed for the first time that NOS inhibitors may control DNMT3b mRNA expression in rat hippocampus. Our results suggest the participation of NO in the cellular pathways related to DNA methylation triggered by unpredictable and uncontrollable stress. Therefore, it is possible to assume that 
NOS enzyme is a putative target to control the consequences of hyperactivation of HPA-axis, DNMT/DNA methylation, and gene expression involved with the neurobiology of major depression.

\section{Conflict of interest and funding}

EC has received lecture fees from Janssen-Cilag. All other authors declare no conflict of interest. This study was supported by Brazilian research agencies FAPESP (\#2015/25067-6, \#2015/06271-1 and \#2017/24304-0; São Paulo Research Foundation Brazil), CNPq (\#306648/2014-8 and \#304780/2018-9; National Council for Scientific and Technological Development, Brazil). For the experiments conducted in Finland, this study was supported by European Research Council, grant \#322742 - iPLASTICITY; EU Joint Programme - Neurodegenerative Disease Research (JPND) CircProt, project \#301225 and \#643417, Sigrid Jusélius Foundation, Jane and Aatos Erkko Foundation, and the Academy of Finland grants \#294710 and \#307416.

\section{Acknowledgment}

The authors thank Flavia Salata (University of São Paulo) and Sulo Kolehmainen (University of Helsinki) for their technical assistance.

\section{Authors' contribution}

ISM designed study, performed the experiments, collected, analyzed and interpreted data, and wrote the manuscript draft. AJS performed the experiments, collected, analyzed data. PCC, EC, CB and SRLJ designed study, analyzed and interpreted data, and wrote the manuscript. 
bioRxiv preprint doi: https://doi.org/10.1101/2020.08.06.240374; this version posted August 6, 2020. The copyright holder for this preprint (which was not certified by peer review) is the author/funder, who has granted bioRxiv a license to display the preprint in perpetuity. It is made available under aCC-BY-NC-ND 4.0 International license.

\section{References}

Adachi, M., Barrot, M., Autry, A.E., Theobald, D., \& Monteggia, L.M. (2008) Selective loss of brain-derived neurotrophic factor in the dentate gyrus attenuates antidepressant efficacy. Biol. Psychiatry, 63, 642-649.

Amitai, Y. (2010) Physiologic role for "inducible" nitric oxide synthase: a new form of astrocytic-neuronal interface. Glia, 58, 17751781.

Anacker, C., Cattaneo, A., Luoni, A., Musaelyan, K., Zunszain, P.A., Milanesi, E., Rybka, J., Berry, A., Cirulli, F., Thuret, S., Price, J., Riva, M.A., Gennarelli, M., \& Pariante, C.M. (2013) Glucocorticoid-related molecular signaling pathways regulating hippocampal neurogenesis. Neuropsychopharmacol. Off. Publ. Am. Coll. Neuropsychopharmacol., 38, 872-883.

Belleau, E.L., Treadway, M.T., \& Pizzagalli, D.A. (2019) The Impact of Stress and Major Depressive Disorder on Hippocampal and Medial Prefrontal Cortex Morphology. Biol. Psychiatry, 85, 443-453.

Biojone, C., Casarotto, P.C., Joca, S.R., \& Castrén, E. (2015) Interplay Between Nitric Oxide and Brain-Derived Neurotrophic Factor in Neuronal Plasticity. CNS Neurol. Disord. Drug Targets, 14, 979-987.

Bird, A.P. (1986) CpG-rich islands and the function of DNA methylation. Nature, 321, 209-213.

Bishop, A. \& Anderson, J. (2005) NO signaling in the CNS: from the physiological to the pathological. Toxicology, 208, 193-205.

Bollinger, J.L., Collins, K.E., Patel, R., \& Wellman, C.L. (2017) Behavioral stress alters corticolimbic microglia in a sex- and brain region-specific manner. PloS One, 12, e0187631.

Calabrese, F., Molteni, R., Maj, P.F., Cattaneo, A., Gennarelli, M., Racagni, G., \& Riva, M.A. (2007) Chronic duloxetine treatment induces specific changes in the expression of BDNF transcripts and in the subcellular localization of the neurotrophin protein. Neuropsychopharmacol. Off. Publ. Am. Coll. Neuropsychopharmacol., 32, 2351-2359.

Campos, A.C.E., Molognoni, F., Melo, F.H.M., Galdieri, L.C., Carneiro, C.R.W., D’Almeida, V., Correa, M., \& Jasiulionis, M.G. (2007) Oxidative stress modulates DNA methylation during melanocyte anchorage blockade associated with malignant transformation. Neoplasia N. Y. N, 9, 1111-1121.

Castrén, E. \& Antila, H. (2017) Neuronal plasticity and neurotrophic factors in drug responses. Mol. Psychiatry, 22, $1085-1095$.

Chandramohan, Y., Droste, S.K., Arthur, J.S.C., \& Reul, J.M.H.M. (2008) The forced swimming-induced behavioural immobility response involves histone $\mathrm{H} 3$ phospho-acetylation and c-Fos induction in dentate gyrus granule neurons via activation of the $\mathrm{N}$-methyl-D-aspartate/extracellular signal-regulated kinase/mitogen- and stress-activated kinase signalling pathway. Eur. $J$. Neurosci., 27, 2701-2713.

Chuang, J.-Y., Kao, T.-J., Lin, S.-H., Wu, A.-C., Lee, P.-T., Su, T.-P., Yeh, S.-H., Lee, Y.-C., Wu, C.-C., \& Chang, W.-C. (2017) Specificity protein 1-zinc finger protein 179 pathway is involved in the attenuation of oxidative stress following brain injury. Redox Biol., 11, 135-143.

Crosio, C., Heitz, E., Allis, C.D., Borrelli, E., \& Sassone-Corsi, P. (2003) Chromatin remodeling and neuronal response: multiple signaling pathways induce specific histone $\mathrm{H} 3$ modifications and early gene expression in hippocampal neurons. J. Cell Sci., 116, 4905-4914.

Dhir, A. \& Kulkarni, S.K. (2007) Involvement of nitric oxide (NO) signaling pathway in the antidepressant action of bupropion, a dopamine reuptake inhibitor. Eur. J. Pharmacol., 568, 177-185.

Dhir, A. \& Kulkarni, S.K. (2011) Nitric oxide and major depression. Nitric Oxide Biol. Chem. Off. J. Nitric Oxide Soc., $24,125-131$.

Diniz, C.R.A.F., Casarotto, P.C., \& Joca, S.R.L. (2016) NMDA-NO signaling in the dorsal and ventral hippocampus time-dependently modulates the behavioral responses to forced swimming stress. Behav. Brain Res., 307, 126-136.

Doherty, T.S., Forster, A., \& Roth, T.L. (2016) Global and gene-specific DNA methylation alterations in the adolescent amygdala and hippocampus in an animal model of caregiver maltreatment. Behav. Brain Res., 298, 55-61.

Duman, C.H. \& Duman, R.S. (2015) Spine synapse remodeling in the pathophysiology and treatment of depression. Neurosci. Lett., 601, 20-29.

Elliott, E., Ezra-Nevo, G., Regev, L., Neufeld-Cohen, A., \& Chen, A. (2010) Resilience to social stress coincides with functional DNA methylation of the Crf gene in adult mice. Nat. Neurosci., 13, 1351-1353.

Fanselow, M.S. \& Dong, H.-W. (2010) Are the dorsal and ventral hippocampus functionally distinct structures? Neuron, 65, 7-19.

Feng, J., Zhou, Y., Campbell, S.L., Le, T., Li, E., Sweatt, J.D., Silva, A.J., \& Fan, G. (2010) Dnmt1 and Dnmt3a maintain DNA methylation and regulate synaptic function in adult forebrain neurons. Nat. Neurosci., 13, 423-430.

Ferreira, F.R., Oliveira, A.M., Dinarte, A.R., Pinheiro, D.G., Greene, L.J., Silva, W.A., Joca, S.R., \& Guimarães, F.S. (2012) Changes in hippocampal gene expression by 7-nitroindazole in rats submitted to forced swimming stress. Genes Brain Behav., 11, 303313.

Finkel, M.S., Laghrissi-Thode, F., Pollock, B.G., \& Rong, J. (1996) Paroxetine is a novel nitric oxide synthase inhibitor Psychopharmacol. Bull., 32, 653-658.

Floriou-Servou, A., von Ziegler, L., Stalder, L., Sturman, O., Privitera, M., Rassi, A., Cremonesi, A., Thöny, B., \& Bohacek, J. (2018) Distinct Proteomic, Transcriptomic, and Epigenetic Stress Responses in Dorsal and Ventral Hippocampus. Biol. Psychiatry, 84, 531-541.

Gallo, E.F. \& Iadecola, C. (2011) Neuronal nitric oxide contributes to neuroplasticity-associated protein expression through cGMP, protein kinase G, and extracellular signal-regulated kinase. J. Neurosci. Off. J. Soc. Neurosci., 31, 6947-6955.

Gassen, N.C., Fries, G.R., Zannas, A.S., Hartmann, J., Zschocke, J., Hafner, K., Carrillo-Roa, T., Steinbacher, J., Preißinger, S.N., Hoeijmakers, L., Knop, M., Weber, F., Kloiber, S., Lucae, S., Chrousos, G.P., Carell, T., Ising, M., Binder, E.B., Schmidt, M.V., Rüegg, J., \& Rein, T. (2015) Chaperoning epigenetics: FKBP51 decreases the activity of DNMT1 and mediates epigenetic effects of the antidepressant paroxetine. Sci. Signal., 8, ra119.

Geoffroy, M. \& Christensen, A.V. (1993) Psychomotor stimulants versus antidepressants in the learned helplessness model of depression. Drug Dev. Res., 29, 48-55.

Gray, J.D., Rubin, T.G., Hunter, R.G., \& McEwen, B.S. (2014) Hippocampal gene expression changes underlying stress sensitization and recovery. Mol. Psychiatry, 19, 1171-1178.

Guix, F.X., Uribesalgo, I., Coma, M., \& Muñoz, F.J. (2005) The physiology and pathophysiology of nitric oxide in the brain. Prog. 
bioRxiv preprint doi: https://doi.org/10.1101/2020.08.06.240374; this version posted August 6, 2020. The copyright holder for this preprint (which was not certified by peer review) is the author/funder, who has granted bioRxiv a license to display the preprint in perpetuity. It is made available under aCC-BY-NC-ND 4.0 International license.

Neurobiol., 76, 126-152.

Herre, M. \& Korb, E. (2019) The chromatin landscape of neuronal plasticity. Curr. Opin. Neurobiol., 59, 79-86.

Higuchi, F., Uchida, S., Yamagata, H., Otsuki, K., Hobara, T., Abe, N., Shibata, T., \& Watanabe, Y. (2011) State-dependent changes in the expression of DNA methyltransferases in mood disorder patients. J. Psychiatr. Res., 45, 1295-1300.

Hiroaki-Sato, V.A., Sales, A.J., Biojone, C., \& Joca, S.R.L. (2014) Hippocampal nNOS inhibition induces an antidepressant-like effect: involvement of 5HT1A receptors. Behav. Pharmacol., 25, 187-196.

Hmadcha, A., Bedoya, F.J., Sobrino, F., \& Pintado, E. (1999) Methylation-dependent gene silencing induced by interleukin 1 beta via nitric oxide production. J. Exp. Med., 190, 1595-1604.

Huang, F.-Y., Chan, A.O.-O., Rashid, A., Wong, D.K.-H., Cho, C.-H., \& Yuen, M.-F. (2012) Helicobacter pylori induces promoter methylation of E-cadherin via interleukin-1 $\beta$ activation of nitric oxide production in gastric cancer cells. Cancer, 118, 49694980.

Jinawath, A., Miyake, S., Yanagisawa, Y., Akiyama, Y., \& Yuasa, Y. (2005) Transcriptional regulation of the human DNA methyltransferase 3A and 3B genes by Sp3 and Sp1 zinc finger proteins. Biochem. J., 385, 557-564.

Joca, S.R., Moreira, F.A., \& Wegener, G. (2015) Atypical Neurotransmitters and the Neurobiology of Depression. CNS Neurol. Disord. Drug Targets, 14, 1001-1011.

Joca, S.R.L., Ferreira, F.R., \& Guimarães, F.S. (2007) Modulation of stress consequences by hippocampal monoaminergic, glutamatergic and nitrergic neurotransmitter systems. Stress Amst. Neth., 10, 227-249.

Joca, S.R.L. \& Guimarães, F.S. (2006) Inhibition of neuronal nitric oxide synthase in the rat hippocampus induces antidepressant-like effects. Psychopharmacology (Berl.), 185, 298-305.

Joca, S.R.L., Padovan, C.M., \& Guimarães, F.S. (2003) Activation of post-synaptic 5-HT(1A) receptors in the dorsal hippocampus prevents learned helplessness development. Brain Res., 978, 177-184.

Joca, S.R.L., Sartim, A.G., Roncalho, A.L., Diniz, C.F.A., \& Wegener, G. (2019) Nitric oxide signalling and antidepressant action revisited. Cell Tissue Res., 377, 45-58.

Karpova, N.N., Rantamäki, T., Di Lieto, A., Lindemann, L., Hoener, M.C., \& Castrén, E. (2010) Darkness Reduces BDNF Expression in the Visual Cortex and Induces Repressive Chromatin Remodeling at the BDNF Gene in Both Hippocampus and Visual Cortex. Cell. Mol. Neurobiol., 30, 1117-1123.

Katayama, Y., Takahashi, M., \& Kuwayama, H. (2009) Helicobacter pylori causes runx3 gene methylation and its loss of expression in gastric epithelial cells, which is mediated by nitric oxide produced by macrophages. Biochem. Biophys. Res. Commun., 388, 496-500.

Kowiański, P., Lietzau, G., Czuba, E., Waśkow, M., Steliga, A., \& Moryś, J. (2018) BDNF: A Key Factor with Multipotent Impact on Brain Signaling and Synaptic Plasticity. Cell. Mol. Neurobiol., 38, 579-593.

Krass, M., Wegener, G., Vasar, E., \& Volke, V. (2011) The antidepressant action of imipramine and venlafaxine involves suppression of nitric oxide synthesis. Behav. Brain Res., 218, 57-63.

Lee, B., Cao, R., Choi, Y.-S., Cho, H.-Y., Rhee, A.D., Hah, C.K., Hoyt, K.R., \& Obrietan, K. (2009) The CREB/CRE transcriptional pathway: protection against oxidative stress-mediated neuronal cell death. J. Neurochem., 108, 1251-1265.

Lin, R.-K. \& Wang, Y.-C. (2014) Dysregulated transcriptional and post-translational control of DNA methyltransferases in cancer. Cell Biosci., 4, 46.

Livak, K.J. \& Schmittgen, T.D. (2001) Analysis of relative gene expression data using real-time quantitative PCR and the 2(-Delta Delta C(T)) Method. Methods San Diego Calif, 25, 402-408.

Lu, Y.F., Kandel, E.R., \& Hawkins, R.D. (1999) Nitric oxide signaling contributes to late-phase LTP and CREB phosphorylation in the hippocampus. J. Neurosci. Off. J. Soc. Neurosci., 19, 10250-10261.

Mahgoub, M. \& Monteggia, L.M. (2013) Epigenetics and psychiatry. Neurother. J. Am. Soc. Exp. Neurother., 10, 734-741.

Maier, S.F. \& Seligman, M.E.P. (2016) Learned helplessness at fifty: Insights from neuroscience. Psychol. Rev., 123, $349-367$.

Maier, S.F. \& Watkins, L.R. (2005) Stressor controllability and learned helplessness: the roles of the dorsal raphe nucleus, serotonin, and corticotropin-releasing factor. Neurosci. Biobehav. Rev., 29, 829-841.

Matrisciano, F., Panaccione, I., Dong, E., Grayson, D.R., \& Guidotti, A. (2016) Epigenetics: From Basic Biology to ChromatinModifying Drugs and New Potential Clinical Applications. In Karpova, N. (ed), Epigenetic Methods in Neuroscience Research. Springer New York, New York, NY, pp. 3-18.

McEwen, B.S., Nasca, C., \& Gray, J.D. (2016) Stress Effects on Neuronal Structure: Hippocampus, Amygdala, and Prefrontal Cortex. Neuropsychopharmacol. Off. Publ. Am. Coll. Neuropsychopharmacol., 41, 3-23.

Montezuma, K., Biojone, C., Lisboa, S.F., Cunha, F.Q., Guimarães, F.S., \& Joca, S.R.L. (2012) Inhibition of iNOS induces antidepressant-like effects in mice: pharmacological and genetic evidence. Neuropharmacology, 62, 485-491.

Morris, M.J., Na, E.S., Autry, A.E., \& Monteggia, L.M. (2016) Impact of DNMT1 and DNMT3a forebrain knockout on depressive- and anxiety like behavior in mice. Neurobiol. Learn. Mem., 135, 139-145.

Musazzi, L., Treccani, G., Mallei, A., \& Popoli, M. (2013) The action of antidepressants on the glutamate system: regulation of glutamate release and glutamate receptors. Biol. Psychiatry, 73, 1180-1188.

Nagy, C., Vaillancourt, K., \& Turecki, G. (2017) A role for activity-dependent epigenetics in the development and treatment of major depressive disorder. Genes Brain Behav.,.

Nava, N., Treccani, G., Alabsi, A., Kaastrup Mueller, H., Elfving, B., Popoli, M., Wegener, G., \& Nyengaard, J.R. (2017) Temporal Dynamics of Acute Stress-Induced Dendritic Remodeling in Medial Prefrontal Cortex and the Protective Effect of Desipramine. Cereb. Cortex N. Y. N 1991, 27, 694-705.

Nott, A. \& Riccio, A. (2009) Nitric oxide-mediated epigenetic mechanisms in developing neurons. Cell Cycle Georget. Tex, 8, 725-730.

Okano, M., Bell, D.W., Haber, D.A., \& Li, E. (1999) DNA methyltransferases Dnmt3a and Dnmt3b are essential for de novo methylation and mammalian development. Cell, 99, 247-257.

Popoli, M., Yan, Z., McEwen, B.S., \& Sanacora, G. (2011) The stressed synapse: the impact of stress and glucocorticoids on glutamate transmission. Nat. Rev. Neurosci., 13, 22-37.

Prast, H. \& Philippu, A. (2001) Nitric oxide as modulator of neuronal function. Prog. Neurobiol., 64, 51-68. 
bioRxiv preprint doi: https://doi.org/10.1101/2020.08.06.240374; this version posted August 6, 2020. The copyright holder for this preprint (which was not certified by peer review) is the author/funder, who has granted bioRxiv a license to display the preprint in perpetuity. It is made available under aCC-BY-NC-ND 4.0 International license.

Riccio, A., Alvania, R.S., Lonze, B.E., Ramanan, N., Kim, T., Huang, Y., Dawson, T.M., Snyder, S.H., \& Ginty, D.D. (2006) A nitric oxide signaling pathway controls CREB-mediated gene expression in neurons. Mol. Cell, 21, 283-294.

Roth, T.L. \& Sweatt, J.D. (2011) Epigenetic marking of the BDNF gene by early-life adverse experiences. Horm. Behav., 59, 315-320.

Roth, T.L., Zoladz, P.R., Sweatt, J.D., \& Diamond, D.M. (2011) Epigenetic modification of hippocampal Bdnf DNA in adult rats in an animal model of post-traumatic stress disorder. J. Psychiatr. Res., 45, 919-926.

Ryu, H., Lee, J., Zaman, K., Kubilis, J., Ferrante, R.J., Ross, B.D., Neve, R., \& Ratan, R.R. (2003) Sp1 and Sp3 are oxidative stressinducible, antideath transcription factors in cortical neurons. J. Neurosci. Off. J. Soc. Neurosci., 23, 3597-3606.

Sahu, M.P., Nikkilä, O., Lågas, S., Kolehmainen, S., \& Castrén, E. (2019) Culturing primary neurons from rat hippocampus and cortex. Neuronal Signal., 3, NS20180207.

Sales, A.J., Biojone, C., Terceti, M.S., Guimarães, F.S., Gomes, M.V.M., \& Joca, S.R.L. (2011) Antidepressant-like effect induced by systemic and intra-hippocampal administration of DNA methylation inhibitors. Br. J. Pharmacol., 164, 1711-1721.

Sales, A.J., Hiroaki-Sato, V.A., \& Joca, S.R.L. (2017) Participation of hippocampal nitric oxide synthase and soluble guanylate cyclase in the modulation of behavioral responses elicited by the rat forced swimming test. Behav. Pharmacol., 28, 19-29.

Sales, A.J. \& Joca, S.R.L. (2016) Effects of DNA methylation inhibitors and conventional antidepressants on mice behaviour and brain DNA methylation levels. Acta Neuropsychiatr., 28, 11-22.

Sales, A.J. \& Joca, S.R.L. (2018) Antidepressant administration modulates stress-induced DNA methylation and DNA methyltransferase expression in rat prefrontal cortex and hippocampus. Behav. Brain Res., 343, 8-15.

Sandoval, R., González, A., Caviedes, A., Pancetti, F., Smalla, K.-H., Kaehne, T., Michea, L., Gundelfinger, E.D., \& Wyneken, U. (2011) Homeostatic NMDA receptor down-regulation via brain derived neurotrophic factor and nitric oxide-dependent signalling in cortical but not in hippocampal neurons. J. Neurochem., 118, 760-772.

Schmidt, H.D. \& Duman, R.S. (2007) The role of neurotrophic factors in adult hippocampal neurogenesis, antidepressant treatments and animal models of depressive-like behavior. Behav. Pharmacol., 18, 391-418.

Sharma, D., Bhave, S., Gregg, E., \& Uht, R. (2013) Dexamethasone induces a putative repressor complex and chromatin modifications in the CRH promoter. Mol. Endocrinol. Baltim. Md, 27, 1142-1152.

Socco, S., Bovee, R.C., Palczewski, M.B., Hickok, J.R., \& Thomas, D.D. (2017) Epigenetics: The third pillar of nitric oxide signaling. Pharmacol. Res., 121, 52-58.

Sousa, N. (2016) The dynamics of the stress neuromatrix. Mol. Psychiatry, 21, 302-312.

Sousa, N. \& Almeida, O.F.X. (2012) Disconnection and reconnection: the morphological basis of (mal)adaptation to stress. Trends Neurosci., 35, 742-751.

Stanquini, L.A., Biojone, C., Guimarães, F.S., \& Joca, S.R. (2017) Repeated treatment with nitric oxide synthase inhibitor attenuates learned helplessness development in rats and increases hippocampal BDNF expression. Acta Neuropsychiatr., 1-10.

Takahashi, T., Kimoto, T., Tanabe, N., Hattori, T., Yasumatsu, N., \& Kawato, S. (2002) Corticosterone acutely prolonged N-methyl-daspartate receptor-mediated $\mathrm{Ca} 2+$ elevation in cultured rat hippocampal neurons. J. Neurochem., 83, 1441-1451.

Ulrich-Lai, Y.M. \& Herman, J.P. (2009) Neural regulation of endocrine and autonomic stress responses. Nat. Rev. Neurosci., 10, $397-$ 409.

Urb, M., Anier, K., Matsalu, T., Aonurm-Helm, A., Tasa, G., Koppel, I., Zharkovsky, A., Timmusk, T., \& Kalda, A. (2019) Glucocorticoid Receptor Stimulation Resulting from Early Life Stress Affects Expression of DNA Methyltransferases in Rat Prefrontal Cortex. J. Mol. Neurosci., 68, 99-110.

van Bodegom, M., Homberg, J.R., \& Henckens, M.J.A.G. (2017) Modulation of the Hypothalamic-Pituitary-Adrenal Axis by Early Life Stress Exposure. Front. Cell. Neurosci., 11, 87.

Vasudevan, D., Bovee, R.C., \& Thomas, D.D. (2016) Nitric oxide, the new architect of epigenetic landscapes. Nitric Oxide Biol. Chem., 59, 54-62.

Vialou, V., Feng, J., Robison, A.J., \& Nestler, E.J. (2013) Epigenetic mechanisms of depression and antidepressant action. Annu. Rev. Pharmacol. Toxicol., 53, 59-87.

Weber, M. \& Schübeler, D. (2007) Genomic patterns of DNA methylation: targets and function of an epigenetic mark. Curr. Opin. Cell Biol., 19, 273-280.

Wegener, G. \& Joca, S.R.L. (2016) Nitric Oxide Signaling in Depression and Antidepressant Action. In López-Muñoz, F., Srinivasan, V., de Berardis, D., Álamo, C., \& Kato, T.A. (eds), Melatonin, Neuroprotective Agents and Antidepressant Therapy. Springer India, New Delhi, pp. 765-792.

Wegener, G. \& Volke, V. (2010) Nitric Oxide Synthase Inhibitors as Antidepressants. Pharm. Basel Switz., 3, $273-299$.

Wegener, G., Volke, V., Harvey, B.H., \& Rosenberg, R. (2003) Local, but not systemic, administration of serotonergic antidepressants decreases hippocampal nitric oxide synthase activity. Brain Res., 959, 128-134.

Xiong, Y., Fru, M.F., Yu, Y., Montani, J.-P., Ming, X.-F., \& Yang, Z. (2014) Long term exposure to L-arginine accelerates endothelial cell senescence through arginase-II and S6K1 signaling. Aging, 6, 369-379.

Yazir, Y., Utkan, T., \& Aricioglu, F. (2012) Inhibition of neuronal nitric oxide synthase and soluble guanylate cyclase prevents depression-like behaviour in rats exposed to chronic unpredictable mild stress. Basic Clin. Pharmacol. Toxicol., 111, 154160.

Zhou, Q.-G., Zhu, L.-J., Chen, C., Wu, H.-Y., Luo, C.-X., Chang, L., \& Zhu, D.-Y. (2011) Hippocampal neuronal nitric oxide synthase mediates the stress-related depressive behaviors of glucocorticoids by downregulating glucocorticoid receptor. J. Neurosci. Off. J. Soc. Neurosci., 31, 7579-7590.

Zimmermann, N., Zschocke, J., Perisic, T., Yu, S., Holsboer, F., \& Rein, T. (2012) Antidepressants inhibit DNA methyltransferase 1 through reducing G9a levels. Biochem. J., 448, 93-102.

Zomkowski, A.D.E., Engel, D., Gabilan, N.H., \& Rodrigues, A.L.S. (2010) Involvement of NMDA receptors and L-arginine-nitric oxide-cyclic guanosine monophosphate pathway in the antidepressant-like effects of escitalopram in the forced swimming test. Eur. Neuropsychopharmacol. J. Eur. Coll. Neuropsychopharmacol., 20, 793-801. 